\title{
The Role of Microcomputer Clubs in the Education of the Polish Youth in the 1980s: A Retrospective Analysis
}

\author{
Karol Król (D)
}

Citation: Król, K. The Role of Microcomputer Clubs in the

Education of the Polish Youth in the 1980s: A Retrospective Analysis. Educ. Sci. 2022, 12, 150. https:// doi.org/10.3390/educsci12030150

Academic Editor: James Albright

Received: 29 January 2022

Accepted: 17 February 2022

Published: 22 February 2022

Publisher's Note: MDPI stays neutral with regard to jurisdictional claims in published maps and institutional affiliations.

Copyright: (C) 2022 by the author. Licensee MDPI, Basel, Switzerland. This article is an open access article distributed under the terms and conditions of the Creative Commons Attribution (CC BY) license (https:// creativecommons.org/licenses/by/ $4.0 /$ )
Digital Cultural Heritage Laboratory, Department of Land Management and Landscape Architecture, Faculty of Environmental Engineering and Land Surveying, University of Agriculture in Krakow, Balicka 253c, 30-198 Krakow, Poland; k.krol@onet.com.pl

\begin{abstract}
In the 1980s, Polish schools hardly had access to computers, particularly at the primary and secondary levels. The main reasons were funds and shortage of qualified staff that could handle computer hardware. As a consequence, the youth first came across a computer, how to use it, service hardware, and write programs outside schools in the early 1980s. Often informal groups of hobbyists gathered around a single computer were the seeds of microcomputer clubs, which cropped up in huge numbers in Poland in the 1980s. The objective of the paper is to portray the role of microcomputer clubs in the process of shaping the youth and computer education in the 1980s in Poland compared to other countries. The conclusions are founded on a literature review. The analyzed material included an Internet Archive collection "The Computer Magazine Archives". The content of one of the first Polish computer magazines, Bajtek Magazine was analyzed in detail. It has been demonstrated that the Polish youth of the 1980s first came across a computer mainly outside schools, primarily in microcomputer clubs. It was the root of computer and information technology education in Poland. Moreover, microcomputer clubs were reported to provide education, as well as foster character education, aid socialization, and shape attitudes.
\end{abstract}

Keywords: computer education; early childhood upbringing; beginnings of computerization; digital heritage; hardware heritage

\section{Introduction}

At the verge of the 1980s, computers were used mostly in university laboratories, corporate offices, sometimes at home, and (universal) education institutions. In primary and secondary schools, computers, if any, were used as teaching aids to develop a sense of control over hardware and foster the teaching process. They were intended as a backbone for an environment for modern learning in many domains, such as music, foreign languages, arts, physics, biology, or mathematics. Furthermore, they were the foundation of an unprecedented type of school where the computer was a universal tool to facilitate learning [1].

Public-funded institutions in Poland and the Eastern Bloc used mostly homemade systems, mainly due to hardware and software availability and pricing in the 1980s. Things were slightly different in places that grew as grassroots initiatives run by computer enthusiasts. In the 1980s, Polish schools had little to no access to computers, particularly at the primary and secondary levels. The main reasons were insufficient funds and a lack of qualified teachers that could handle the hardware. Note that it was not only in Poland but in most countries that computers were a rarity in the 1980s. Schools could not afford to buy computers or teach computer and information technology. A home computer was not a common sight, either. Nevertheless, any such system attracted fascinated young people. Often, informal groups of hobbyists gathered around a single computer were the seeds of microcomputer clubs, which cropped up in huge numbers in Poland in the 1980s. As a consequence, the youth first came across a computer, how to use it, service hardware, and write programs outside schools in the early 1980s. 
Most research publications on computer education focus on the future: modern technologies and trends in teaching [2], learning, and technology-aided education (today and in the future) [3], socio-educational perspectives of guiding children and youth, and new instructional techniques, models, and tools [4], including remote education [5]. It suggests that analysis of certain historical phenomena that affected the education and formation of the youth is less popular. The general development of computer education has its origins that illustrate its path. It opens a research gap, which encompasses the phenomenon of microcomputer clubs in Poland in the 1980s. The objective of the paper is to portray the role of microcomputer clubs in the process of shaping the youth and computer education in the 1980s in Poland compared to other countries.

The remainder of this paper is structured as follows. Section two depicts the beginnings of computerization and the activity of microcomputer clubs in Poland in the 1980s. It presents a computer magazine, Bajtek, which documented the history of clubs with its BAJTEK Golden Disk Contest (O Złota Dyskietkę BAJTKA). The third section presents the retrospective research methodology, the sources, and keywords. The results are shown in section four, which focuses on characterizing microcomputer clubs, venues, the scope of activities, organizational structures, and the socioeconomic conditions of the clubs. The fifth section discusses the activities of the clubs, including education and attitude-building and early computer education curricula in selected countries. The summary demonstrates that the clubs were established to integrate computer users, train new personnel, exchange experience, hardware, and software, build relationships and offer entertainment.

\section{Background}

The notion of a "club" was characteristic of 1980s Poland when various types of neighborhood, afternoon, or workplace clubs were established to integrate local communities. Microcomputer clubs were places for learning about the structure of the computer and how to operate it. The primary mission of the clubs was to promote computer education among young people, gather and disseminate information concerning informatics and its application, and create universally available microcomputer programs-all this required hardware and software. Albeit many such communities did not even have their own systems on day one. Young people and tutors often had to rely on discussions, computer press and literature, and mock-ups of actual systems or their functional simulations (as was the case with the in-school club Szkolne Kółko Komputerowe in the W. Broniewski Second Secondary School in Koszalin). The process of learning programming languages without a computer was referred to as "dry" learning [6]. For this reason, only the most persistent members persevered after some time. Users who wanted to pursue a passion not only have a nice time with a video game.

Many members were rather ambitious. Sponsors and tutors in the clubs wanted to prevent any associations with gaming dens. They strove to direct children's attention towards learning the basics of informatics and electronics, studying programming languages, and putting together computer programs rather than focusing on games [6]. Most clubs activities focused on education, attitudes, and social development. Note that the clubs were run by enthusiasts skilled at operating computers who were scarce in Poland in the 1980s.

The clubs were set to shape innovative attitudes, cross awareness barriers, and offer broad computer education as part of the technical education of the youth [7]. Members of the clubs focused on learning the structure of hardware and arcana of programming. According to press reports, pupils who attended microcomputer clubs wrote their original programs, mostly educational ones. Only some accounts mentioned computer games that were allocated limited time, primarily spare time. The authors emphasized that all club members were good students (meaning the computer did not invade their learning time). Many were even finalists of official school subject contests [8]. Therefore, the reports focused on the educational merits of computer systems that were to be used for practical applications, not entertainment. Still, many started their computer journey with computer games and did not progress from there. The analysis yielded a research 
hypothesis that computer education in Poland started from microcomputer clubs. It was due to the fact that computer education happened mostly outside school because schools did not have sufficient funds or computer systems. Moreover, a hypothesis is proposed that microcomputer clubs provided education, as well as fostered upbringing, aided socialization, and shaped attitudes.

\section{BAJTEK Golden Disk Contest}

The Bajtek magazine is an invaluable source of insight into the reality of microcomputer clubs in Poland in the 1980s [9]. It was one of the first high-circulation computer journals in Poland and quickly became popular. It was published from 1985 to 1996 and was highly appreciated by computer aficionados in its peak [10]. It was because many readers of the computer press in Poland did not have a computer and wanted "at least to taste the modernity and global trends" [7]. Today, Bajtek is a symbol of early computerization in Poland in the 1980s.

The idea of the Bajtek computer magazine was conceived in mid-1985 by journalists who later edited the Komputer monthly. It was initiated by Władysław Majewski and Marek Młynarski [11]. The project quickly turned out to be a success. It was the beginning of home computer import, and people were eager for computer knowledge [12]. The same year, state-controlled stores, Pewex offered the first Ataris [13]. Polish users could also obtain ZX81 Sinclair and ZX Spectrum manufactured since 1982 [11]. The trend did not go unnoticed by the Polish United Workers' Party (the ruling communist party in the Polish People's Republic), which wanted to emphasize the educational nature of the magazines and their potential to shape young people [14]. It had a significant impact on the content of virtually any journal in Poland, including Bajtek. Note that the computer press at the time had to tackle technical challenges, such as small rations of paper or even lack of paper, problems at print shops, censorship, and problematic distribution. Moreover, the editorial teams of the magazines did not work together. They established slightly hermetic, rivaling circles [11].

To have a computer at home in the dull reality of the 1980s Polish Peoples' Republic was something magical. Therefore, school pupils aged 7 to 15 and secondary school students were immensely enthusiastic about computer systems. The Internet was unavailable at the time, and the sources of information were the press and TV news, such as Teleexpress (a news magazine broadcast by the Polish Television every day since 1986 till today) or Telewizyjny Kurier Warszawski (the oldest news magazine of the Polish Television broadcast today since 1958).

Bajtek held various contests at the time, such as crosswords or the Christmas competition. Answers were submitted by mail and often came in tens of thousands. Some contests elicited nearly a hundred thousand letters that were verified, and the winners were picked at random [15]. However, the Bajtek Golden Disk Contest, announced in the 1980s caused an unprecedented flood of responses.

The Bajtek Golden Disk Contest presented the backstage details of microcomputer clubs from all over Poland. It was held under the auspices of the Minister, Member of the Council of Ministers for the Youth and supported by the Association of Rural Youth, Polish Scouting and Guiding Association, Tournament of Young Masters of Engineering of the Polish Socialist Youth Union, and the Central Warehouse of the Scouting and Guiding Association. The contest was open to all microcomputer clubs: workplaces, schools, youth organizations, and community centers. In addition, Bajtek accepted submissions from informal clubs as well. The prize, microcomputer Amstrad 6128, was sponsored by the Minister for the Youth [16]. The two editions of the contest attracted several dozen microcomputer clubs from all over Poland (Table A1).

The first edition of the contest took place in 1987, and the winner was the MERIZAP club at the MERIZAP Complex of Technical Schools [17]. The second edition was announced in October 1988 [18]. The organizers noted that microcomputer clubs in Poland had to face numerous issues, such as how to organize meetings (curriculum), what to 
teach, should computer games be promoted, and how to secure funding. The contest was intended as a presentation of the achievements and ideas of clubs and dissemination of good teaching, organizational, and economic practices. The following criteria were evaluated [18]: the public footprint of the club, accessibility and openness, tangible effects (such as original software), educational and promotional activity, independent acquisition of hardware and aids, delivery of various levels of training, and innovative forms of activity.

\section{Materials and Methods}

Research on digital cultural heritage tends to employ retrospective analysis, focusing mainly on archaic hardware and software with the associated socioeconomic and cultural environment [19]. Such analyses are founded on archival materials, including research journals, science magazines, and databases [20].

The foundation of the present work is a literature review that included research papers and 1980s industry literature. Archival materials were obtained from the Internet Archive. The analyzed material included a collection of "The Computer Magazine Archives". The content of one of the first Polish computer magazines, Bajtek Magazine was analyzed in detail. Archival issues were browsed manually or using the Internet Archive's search engine and the following keywords: edukacja (education), konkurs (contest), złota dyskietka (golden floppy disk), kluby (clubs), and kluby komputerowe (computer clubs). The search was facilitated by the organizational structure of the magazine and its division into sections or clans addressed to users of various platforms, such as Atari, Commodore, ZX Spectrum, Amstrad, and IBM $[10,21]$. The background for the analyses was a presentation of selected socioeconomic phenomena relevant to the availability and sale of computer hardware in the Polish People's Republic and neighboring countries.

Retrospective (ex-post) analyses help track the evolution (history) of a phenomenon and potentially forecast (model) the future with secondary data analysis. A retrospective analysis is a "glimpse into the past" from the perspective of the known effect of an event. It most often involves a search for factors that could lead to the known outcomes, results, and consequences. They can often determine the trend line, maximum $/ \mathrm{minimum}$, and outliers and use the data to forecast future behavior or tendencies. Retrospective analyses help understand what we call the present (current state) better by analyzing the "evolutionary path" or the cause-and-effect. They are used for such endeavors as retrospective literature reviews [22,23], analyses of the impact of new technology and computers on education [24,25], education quality research, analyses of deployment of new technologies [26], and analyses of causes and consequences of socioeconomic phenomena [27-29]. Furthermore, retrospective research is used in medicine and environmental quality and condition research [30,31]. It is also successfully employed in pilot research to build hypotheses and plan prospective research.

\section{Results}

The 1980s saw computer (or microcomputer) clubs crop up all over Poland, both in rural and urban areas, but usually in places where at least one computer was available. The clubs were established at workplaces, municipal community centers, neighborhood clubs, or school community centers (Figure 1). Members of the clubs were mostly boys because, as they put it, "girls are not really interested in computers, at least for now" [8]. The same pattern was noted in other countries [32].

The government of the People's Republic of Poland did not want computer clubs to be associated with social life or entertainment. It was consistent with the idea behind the clubs; their primary function was to educate, give young people a purpose and a way to spend time, and secure a future expert IT workforce. Therefore, representatives of the clubs stressed the youth had access to hardware, knowledge, a tutor, computer magazines, and utility software in the clubs [33]. For the members, the crucial components were a separate space, companions, community belonging, the atmosphere of something special, and a computer, of course, at least one. Still, computer club hardware resources were 
mostly modest, to say the least (Table A2). For example, the municipal community center in Raciazżek established the Bajtek computer club in April 1986. Initially, it had only one Commodore C-64, two Neptun monitors, a magnetic tape storage device, printer, and disk drive.

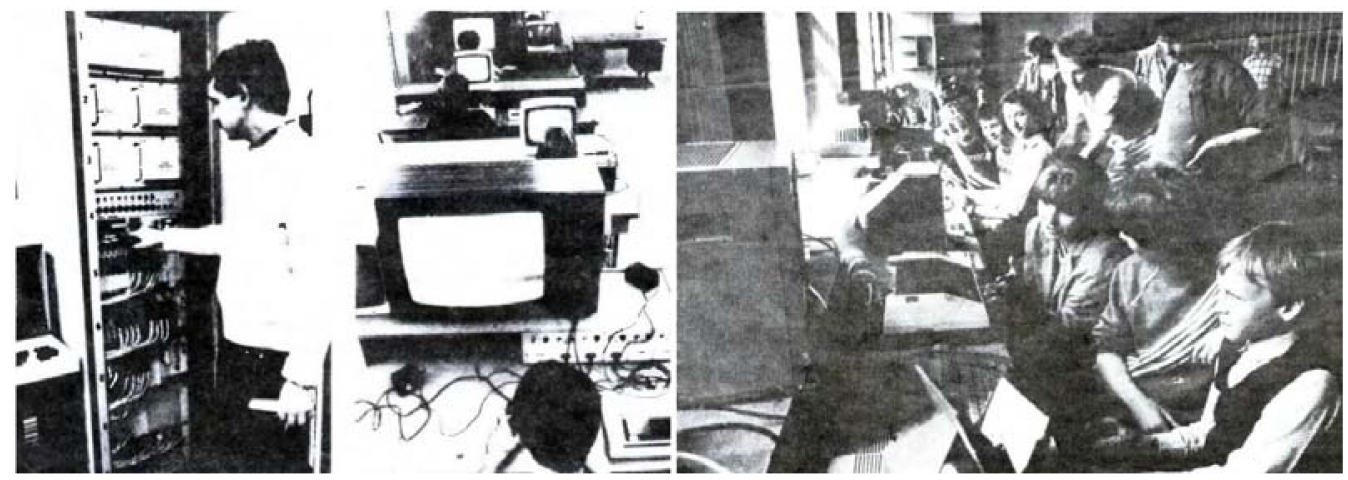

Figure 1. Left to right: the MERIZAP club computer room (Ostrów Wielkopolski, 1987). Source: [16]. The opening ceremony in the Bajtek microcomputer club in Bytom (1987). Source: [33].

The club was attended mostly by senior primary school students and secondary school students. The clubs operated according to specific rules. Tutors delivered the classes on selected days of the week at specific times. Apart from learning, the members had time for fun, but it was to enhance the educational effort. Press accounts emphasized that the members strove to find out how games were written and modify them [33]. Not all clubs had many members. Still, it was not necessarily bad for those who had one or a few computers and modest budgets. For example, the microcomputer club FUTURE in Oleśnica had 12 members in 1989, and half of them had a computer [34].

\subsection{Workplace Computer Clubs}

Some clubs were established for residents of specific neighborhoods, but others focused on educational institutions, cultural venues, or production facilities. One of the latter was MNEMONIK, a microcomputer club established in an electronics factory Zakłady Elektroniczne ELWRO in Wrocław in 1986. "MNEMONIK" has a meaning in assembler languages, but in Polish, it is another word for a mnemonist, a person with outstanding memory.

Zakłady Elektroniczne ELWRO in Wrocław has significantly contributed to the development of informatics in Poland. The computers constructed and manufactured by ELWRO were used to computerize institutions, businesses, and entire industries in Poland. In 1986, ELWRO manufactured a pilot line of school personal computers, the Elwro 800 Junior for teachers and students [35]. The Elwro 804 Junior was a home-use personal microcomputer for work, learning, and entertainment. It could also aid with data processing in businesses. The computers were first mass-produced in 1987 and were quickly deployed in several thousand schools in Poland. Many students and teachers were trained with this hardware.

The fact that the club was established in ELWRO put it in an excellent position. The members had access to the ELWRO Junior. However, the club had other functions as well. It promoted homemade IT products and educated and trained the next generation of IT technicians. The club also affected the image of ELWRO. MNEMONIK was a founding club of the Polish Foundation for Computer Education where it provided training on the use of computers in teaching children with special needs [34]. Therefore, computer clubs played important public roles both on the local and national levels.

CELBIT computer club was established under the auspices of a cellulose factory Zakłady Celulozowo-Papiernicze in Kwidzyn. It was by no means accidental. To modernize the production line, the management needed computers and trained personnel. The club was meant to give young people access to hardware and education and trained qualified staff. 
CELBIT had three Timexes, one Polbrit, and Ataris 800XL (all with peripherals) [9]. In 1987 , the club had over 200 members. It was located in a local community hall in Zatorze II, and then in the city community center. It was famous for numerous industrial events. Another workplace computer club was Złoty Amstrad established in 1987 in a plastics and paint factory Zakłady Tworzyw i Farb in Złoty Stok. The club collaborated with primary schools in Złoty Stok and helped the students learn how to use a computer. The club classes were divided into two sections: programming and computer games. The programming section focused on LOGO and Turbo Pascal and program writing in dBase. In 1989, the club had 130 permanent members, part of whom participated by mail only [9].

\subsection{Character and Attitude Building}

The clubs also shaped the young people. Many of them offered additional educational classes where the participants could watch popular science films, for example, or edited and published educational brochures in addition to computer education [9]. Apart from clubs in workplaces, which focused on educating future personnel, computer clubs were also shaping the youth and building their attitudes. A good example is a scout's club Harcerski Klub Komputerowy HarcBajt from Gańsk.

The education in the clubs was most often organized as non-school classes. It was not uncommon for the classes to take place every day and last several hours [16], as was the case in HarcBajt. One day of the week was a gaming day open to all. In addition to computer education, the club developed general technical skills. The members' activity involved speculative fiction as well [9].

Sometimes, club members helped teachers break the computer ice-it was not easy to find computer-qualified educators in the 1980s. Often students brought their computers to classes and prepared lesson plans to give others access to new systems. Clubs held training courses for teachers as well. A good example is the 105-h training course for primary school teachers that included BASIC and the Spectrum. Its other part focused on PASCAL and LOGO [16].

\subsection{Informal Clubs}

Microcomputer clubs strove to stand out among others. Most of them were formalized and had curricula to guide the learning process, but some were much more individualized. One of such less formal organizations was Mr. ATARI from Kozienice. According to its members, they operated without strict requirements, clear objectives, or a policy. It was partially because its members would meet in small groups at homes and then exchange experiences. The founders of the club had no patron or sponsor and were adamant opponents of principles and guidelines. The members considered their contact with the computer as a fun time [16].

Members of some clubs, like BOBAS-ATARI from Gliwice, said they were not actually a club but a group of friends with shared interests. They declared the club was open to anyone who could conform to a single prerequisite: be likable. They did not pretend games were not their primary focus. They had no fixed days or venues for their meetings, paid no membership fees, and had no membership cards. They met at home when they felt like it. The club members emphasized that computers brought them together [8].

Computer clubs could also be family organizations. BIT from Warsaw was a unique family computer club of four members of the Ziembinscy family. The club, if the term could be stretched to cover a family of four, had a slightly different attitude towards computers as they were more a source of entertainment. According to the "club members" the computer time was considered entertainment. The family treated their computer activity as a club operation because they often had visits from other computer aficionados [16].

\subsection{More Than Just Local}

Larger, more formalized clubs, usually in workplaces, were engaged in broader activities outside of local training meetings. For example, MIKROS from Warsaw obtained 
hardware and software from various Polish companies and collaborated with the Polish Television in its DIY show "Majsterklepka". Via TV, the club members built a mail computer club. Many clubs forged international contacts, primarily by mail [36].

Clubs that had sponsors, tutors, or patrons could count on their aid to tackle financial and organizational obstacles. It was not uncommon in smaller localities that club tutors were the only people around or in the town with the knowledge and skills necessary to use a computer and deliver programming courses. On the other hand, so many young people found computers fascinating that only the chosen few could attend classes in clubs with one or few machines. Here, an example is the FENIKS computer club in Recz where only one-fourth of those interested could be admitted, and there was only one teacher in the town who could use a computer, the founder and tutor in the club [37].

The club activity was supplemented by associations. Stowarzyszenie Mikrokomputerowe ABAKUS was established in 1984 to continue the effort of the first Polish microcomputer club started a year before. It was necessary to guide the development of computer clubs in Warsaw better. In 1984, ABAKUS operated five computer clubs with two community centers offering several dozen microcomputers, including the Atari $800 \mathrm{XL}$, Commodore C64, ZX Spectrum, Amstrad 464, and Schneider PC 1512 [33]. The association focused on the promotion of computerization, building of computer culture, and education. According to the association, the public in Poland was craving for computer education and promotion, such as computer events, contests, lectures, and seminars in the mid-1980s. Its members intended to write and share their software as well.

\section{Discussion}

The process of equipping schools with computers was slow in Eastern Europe, including Poland, in the 1980s. Research shows that most educational institutions did not have a single computer. "Computer lessons" were often optional and employed pen and paper without access to actual hardware. The main reason was insufficient funds to acquire computers, geopolitics, and the shortage of staff who could operate and maintain computers. Still, young people were very curious, to begin with, and grew even more interested as they came across rare computers brought from abroad or bought for foreign currency. The labor market was also eager for new experts. These circumstances created the space for out-of-school computer education, quickly filled in by microcomputer clubs. They took over the education (and partially upbringing) of young people in the 1980s in many countries to some extent.

\subsection{Great Expectations, Even Greater Aspirations}

The state of the computer industry in the early 1980s in Poland was relatively good among Eastern Bloc countries, but mere ten years later, it was dubbed a "hardware museum in the middle of Europe". Other countries, such as Bulgaria, mass-produced computers (the PRAWEC and VAC) and were ahead of Poland in terms of technology. The average Pole living in the late 1980s associated microelectronics mostly with TV advertisements of computers and various "stumbles" of the central and local governments that were always the fault of new computer systems. According to Bolesław Szafrański, computer technology was frozen at the artisan level in 1989 Poland. Many gifted researchers and technicians were mainly putting together systems from parts imported from Taiwan, Singapore, or South Korea [38]. Authors pointed out that Poland did not produce parts at home, such as reliable microprocessors. Computer prices were high, and no systemic changes were made to streamline processes with computers. What made the matter worse, electronics were expensive and perceived as luxury goods, which hindered its public perception [38]. This resulted in great expectations from and ambitious plans of computer clubs.

\subsection{Microcomputer Clubs as the Breeding Ground for the Intelligentsia}

It was not an easy task to establish a professional microcomputer club in the 1980s. Roland Wacławek listed several obstacles, mostly organizational and financial ones, such 
as securing a venue, hardware and software, teaching aids, and engagement of the required personnel, teachers, and instructors. Still, even staff and hardware were not a guarantee of success [39]. According to Wacławek, it was necessary to build an "authentic environment", the right atmosphere and culture for hardware and software contact, and a mind-frame change (Figure 2).

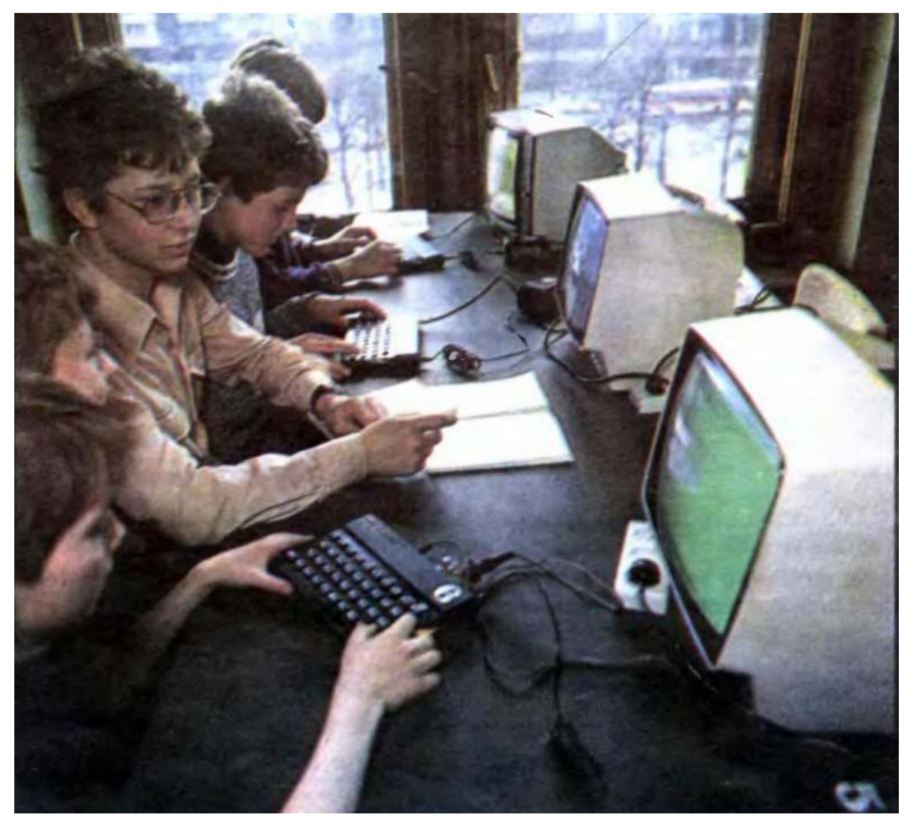

Figure 2. Basic computer science laboratory, electronics and modelling department of the Palace of Youth in Warsaw (the ZX Spectrum, 1983). Source: [7].

In the early days, microcomputer clubs in Poland were set to gain the attention of potential members, which required publicity. There was nothing wrong with it. On the contrary, it promoted computer science, establishing new relations, and finding sponsors, all of which were necessary. Still, it could negatively impact the most talented members whom Wacławek believed to be introverted and potentially perceived as asocial persons in the 1980s. "Computer geeks" did not appreciate crowds or hustle. Still, social life thrived in many microcomputer clubs in Poland. The clubs were places where friendships were born. They were considered venues where people could meet and play computer games or just use a computer. However, Wacławek believed that norms of behavior, manners, and intellectual culture should be adhered to in the clubs. The clubs should be used to expand horizons and interests, not provide entertainment and company. A computer club should be a breeding ground for the intelligentsia proper, people who can offer something more than just education with a diploma to vouch for them. The clubs should educate active people with the right mindset and attitudes towards problems of science and technology. They should help computer enthusiasts, shape the proper intellectual backbone, and integrate those dealing with computers. Moreover, members should have computers at home and school and come to the club only to self-improve and meet professionals. The club should have access to international literature, technical files, and a diversity of systems. All this was hard to achieve. In the 1980s, even the simplest, and elsewhere cheap, computers were luxury goods in Poland. In addition, many computers in Polish clubs were good mainly for basic computer courses and entertainment. As a consequence, people with substantial computer knowledge who had computers at home and work did not frequent the clubs. Besides, many computer experts did not want to promote expert knowledge for fear of losing their "advantage and position" gained with their experience [39]. 


\subsection{Microcomputer Clubs in the World}

Microcomputer clubs were found all over the world. Members of Złoty Amstrad from Złoty Stok had lively correspondence with clubs from nearby countries, the Soviet Union, Czechoslovakia, Hungary, and Bulgaria. It was because the club focused on Amstrad computers, which were rather popular there. Złoty Amstrad was the first Polish microcomputer club with international partners [9].

Microcomputer clubs were found in many countries that are now EU member states and in the East (Russia, for example). One of such clubs was located in Bremen, former Federal Republic of Germany (Bundesrepublik Deutschland in German, West Germany, 1949-1990). Pfadfinder Computer Club was operating under the auspices of the UNH power company. It was established following the example of a Polish club HarcBajt visited by the founders of Pfadfinder Computer Club in 1987. They were surprised by the popularity of microcomputer clubs in Poland and wanted to start a similar organization in their city.

In 1987, Pfadfinder Computer Club found a sponsor, SIEMENS, which funded PC SIEMENS computers with software. The official opening ceremony took place in the UNH factory on 2 February 1988. Forty-eight out of 237 candidates were selected due to hardware, venue, and personnel limitations. The clubs provided education and attitudebuilding activities in groups of eight. The basic training was in general computer and peripherals use. Hamburg and Berlin also had computer clubs in the 1980s. They were crucial because computer (informatics) education started relatively late in the Federal Republic of Germany [40].

Many microcomputer clubs in Moscow (the Soviet Union) followed similar principles to those in Poland. Rooms and hardware were similar, except keyboards, perhaps, that had different labels [32]. AGAT (Moscow) stood out as a payable service. To enter the club, guests had to buy a ticket. One hour in a room with the simplest Soviet homemade computers, the Mikroshas was 50 copecks. An hour in a room with slightly more advanced AGAT computers was 1.2 rouble. The club admission for non-members was payable for all who wanted to use the computers, but the fee covered an instructor and a library of programs as well. This solution, to some degree, resolved the issue of excessive numbers of people who might want to use the computers and provided funds for tutor remuneration and other overheads.

The AGAT was assembled in the Lianozovo Electromechanical Plant. The annual output was about three thousand units. Club AGAT was established in 1986 and had two computer rooms and a technology laboratory from day one, thanks to its patron. The club also housed the first computer rental in Moscow. It cost 80 copecks to rent the Mikrosha for a day. The AGAT was 6.5 rouble a day. The difference was due to the value of the computers. The Mikrosha cost approximately 500 roubles in the 1980s, but the AGAT was much more expensive at 4900 roubles. The club had a dynamic programmer section and focused more on science, technology, and commercial activities. Employees of the plant were very active users, and the club made a profit and became famous, which helped the image of the plant [32].

\subsection{Who Were the Users of Microcomputer Clubs?}

According to the Higher Komsomol School, most of the attendees in Soviet computer clubs were 30 or less $(91.3 \%)$. The largest groups of young people came from primary schools $(66.1 \%)$, technical secondary schools $(10.5 \%)$, and higher education institutions $(6.8 \%)$. Most of the clubs had several to several dozen members. Thirty-six percent of clubs in the Soviet Union had over 100 members in 1989; 20\% of the respondents belonged to clubs with 30 to 50 members. Small clubs with up to ten members amounted to $24 \%$. Merely $14.6 \%$ of the members had a computer at home, most often the Soviet BK-0010 and Japanese Yamahas and the Mikrosha and DWK. Access to computers was limited. This did not stop the authorities from deploying a new subject in Soviet schools, which was rather innovative for the time: introduction to computer science and computation techniques [32]. 
The results of the Higher Komsomol School were consistent with sociological research on computer clubs in Poland. The club lifespan usually did not exceed three years. Moreover, all respondents stressed the need for more computer units [32].

All farmer associations in Czechoslovakia (a Central-European state dissolved in 1992) had microcomputers in the mid-1980s. Computers could also be found in schools, universities, and youth clubs [41]. One of such clubs (T-Klub) existed in Bratislava in 1987 under the auspices of the Czechoslovak Socialist Youth Union. It welcomed all interested in microelectronics. All club members could access computers freely (the Czechoslovak PMD). In addition to video sessions and gaming tournaments, the club had more ambitious goals. It held software fairs, screenings of training videos, and basic programming courses for clubs and informal groups from the entire country. It also offered distance learning and published information brochures. The club was open every day, and its resources were available to students at the Slovak Higher School of Technology and secondary schools. The primary attendees were school students [41].

Education and consulting were the most time-consuming activities in the club, but its leaders had higher aspirations. Education and upbringing were to be complemented with research and production. The plan was to start an experimental, small-scale production of unique computer prototypes in 1987-1988. Plans of the prototypes were complete thanks to the "Electronics every day" contest held by T-Klub in the school year 1986/87. The contest was addressed to young designers. The devices had to be cheap to manufacture. The component costs were limited to two thousand and one thousand korunas depending on the category. The first prize was four thousand korunas, while the average salary in Czechoslovakia in 1987 was three thousand korunas [41].

When some countries were at the beginning of computer education in schools, others were gaining momentum in this regard. In the late 1980 s, $94.9 \%$ of schools in the USA used computers for educational purposes to various degrees. Several years earlier, only $16.5 \%$ of them had computers. The trend was clear. The computer was becoming the centerpiece of the teaching process, and new technologies were to become as commonplace as a pencil or notebook. School computerization in the USA was far from uniform, but relatively cheap personal computers helped accelerate the process [32].

\subsection{Early Computer Education in Curricula-The USA}

In the 1980s, computers were a new thing not only in Poland but the entire world. Manufacturers of computer systems were aware of the need for user education, coupled with the promotion of computers and their applications. Education bridged the gap between the user and the computer, still a novelty in the 1980s. It also promoted and propagated new technologies for everyday use. Higher education institutions, students, teachers, and administration personnel were a significant market. It paid off to invest in school education programs that made use of computers. Therefore, the 1980s saw various (education, technology, socioeconomic, and deployment) projects to educate about computers and with computers. The projects were implemented in schools where pupils had access to computers from early on. Because costs of hardware, research, and curricula usually exceeded the capabilities of the (public) education system by a large margin, computer industry stakeholders were invited, such as MIT Logo Group or Texas Instruments. The goal of the projects was to create conditions where access to computers would not limit learning and find out what students could learn under such circumstances. The first findings in such projects were the ease with which the youngest users of four to nine years used basic computer functionalities (Figure 3) [1]. 


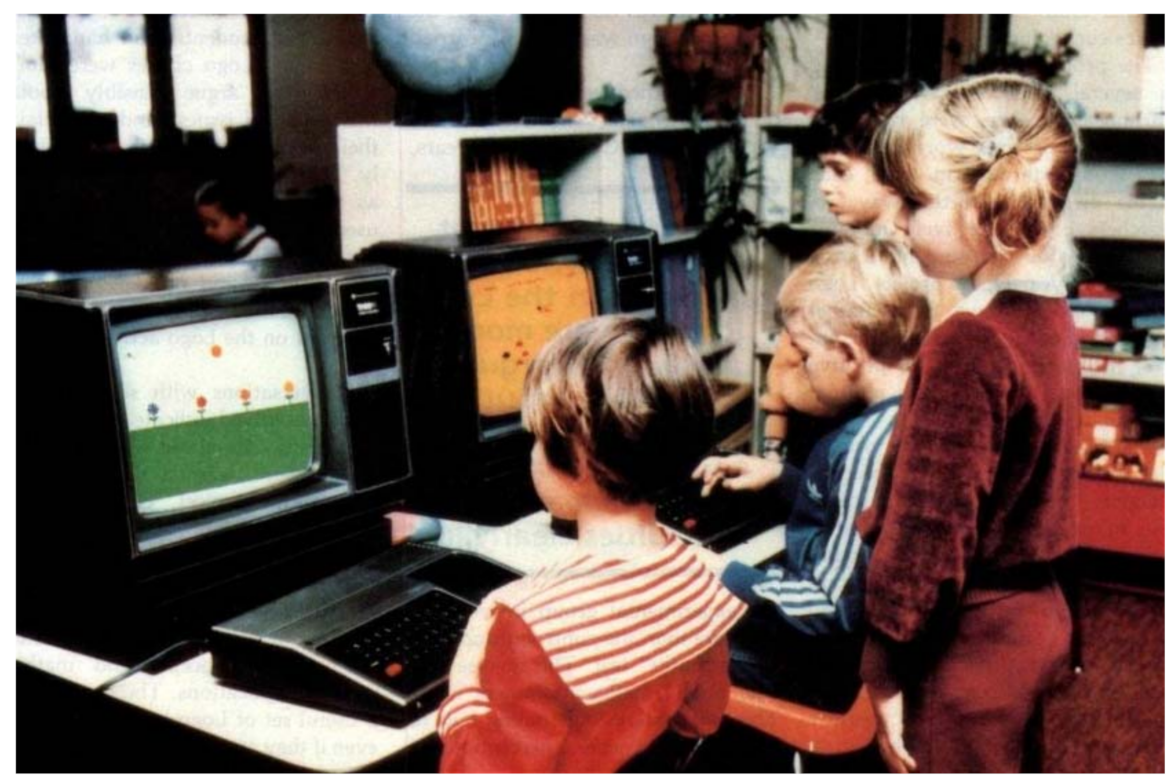

Figure 3. Preschoolers using LOGO TI at Lamplighter School in Dallas, Texas. Photograph courtesy of Texas Instruments Inc. Source: [1].

A good example is the collaboration of Tandy Corporation/Radio Shack and teachers to introduce computers to the curriculum, including educational software and hardware (Figure 4). What Tandy Corporation/Radio Shack did by sponsoring teacher training courses, a nationwide grants program, and educational conferences was a textbook example of corporate social responsibility. The Education Division at Radio Shack designed a courseware library with curriculum experts to provide high-quality training materials for students. Moreover, Radio Shack held free training seminars for teachers at Radio Shack Computer Centers that covered BASIC or Pascal programming, among other things [42].

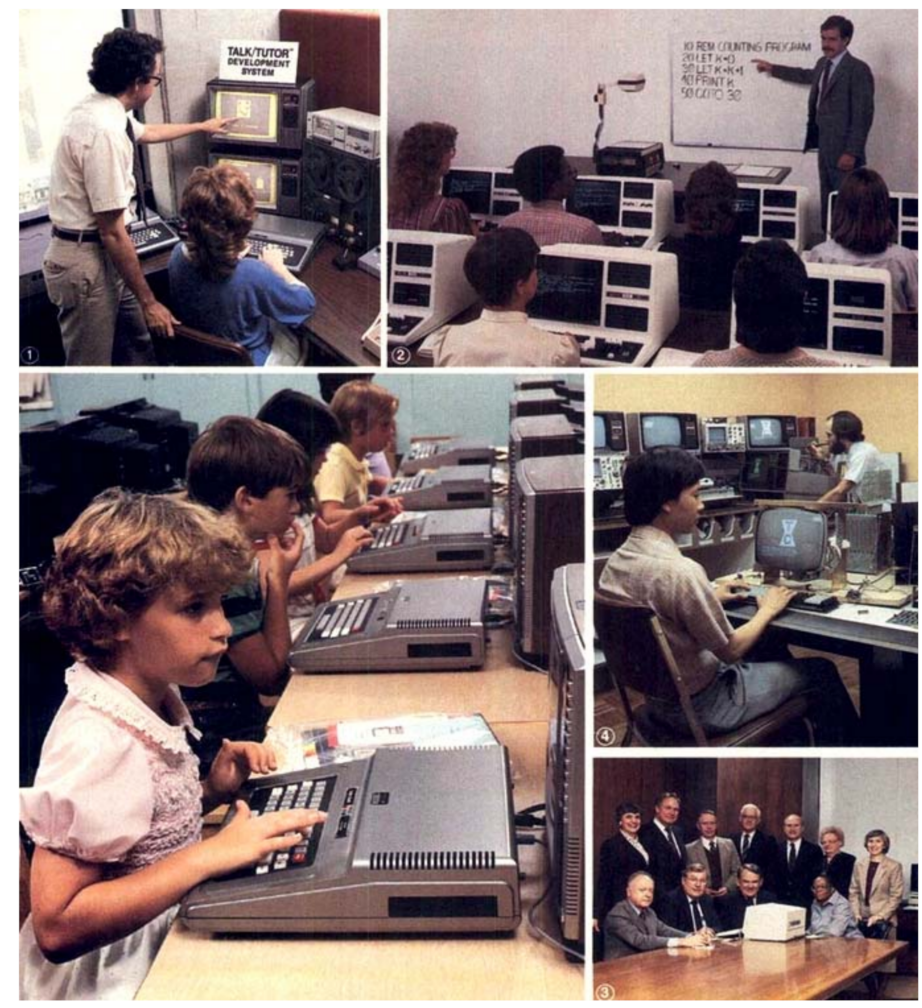

Figure 4. Radio Shack's commitment to education. Source: [42]. 
In 1984, Tandy Corporation/Radio Shack joined the continuing education program at the University of Texas, Austin to sponsor a conference on computer use in education. It was presented as a place to discuss applications, benefits, and developments in educational computer use. The other conference in spring 1985 was another opportunity for educators to stay up to date with educational computer technology [42].

\section{Conclusions}

Every microcomputer club holds stories from the socioeconomic development of Poland. They were places where the youth culture was shaped as a distraction from the dull reality of the Polish People's Republic. Their characteristics varied significantly. Some had rich sponsors or support from organizations, often technical. Others were driven by social or even family life. Chosen few had valuable computer systems, others had to make do with a single private machine, others still had no hardware at all.

Microcomputer clubs provided education as well as fostered character building, aided socialization, and shaped attitudes. They united young people attracted by a strong magnetism of common interests. They played the roles of community centers and youth centers and gave their members a sense of belonging to the growing family of computer aficionados. Many couples met in front of computers, working together in a microcomputer club [6]. This way, computers literally brought people together.

The primary goal of microcomputer clubs in the 1980s was to teach and integrate computer users, allow them to learn, exchange experience, hardware, and software, but also present how a computer could be used for work at home and at school. Most of them did not have fancy machines or spacious premises but still managed to attract large numbers of people passionate about computers. They were often the only places nearby where technology enthusiasts could meet and have access to software, hardware, and accessories that were rare in the 1980s. The space to exchange experience, present (programming) results, and forge new contacts was invaluable. As the availability of computers grew and the Internet stepped in, they were replaced by Internet cafés. Today's more or less formal groups of highly-specialized hobbyists, gamers, or aficionados look nothing like club computers of the early days of computerization.

Funding: Funded with a subsidy from the Ministry of Science and Higher Education for the University of Agriculture in Krakow for 2022.

Institutional Review Board Statement: Not applicable.

Informed Consent Statement: Not applicable.

Data Availability Statement: All trademarks and registered trademarks mentioned herein are the property of their respective owners. The company and product names used in this document are for identification purposes only. The source of the figures: Internet Archive (https://archive.org/, accessed on 29 January 2022). Access to the Internet Archive's Collections is provided at no cost and is granted for scholarship and research purposes only.

Acknowledgments: The author wishes to express his gratitude to the reviewers for their constructive criticism, which contributed to the final content of the paper. The paper was written at the Digital Cultural Heritage Laboratory (https:/ / culturalheritage.urk.edu.pl, accessed on 29 January 2022) part of the Department of Land Management and Landscape Architecture at the Faculty of Environmental Engineering and Land Surveying of the University of Agriculture in Krakow, Poland. The research was carried out as part of the scientific project entitled: Digital cultural heritage of rural areas (2021/05/X/HS3/00859) financed by the National Science Center Poland.

Conflicts of Interest: The author declares no conflict of interest. The funders had no role in the design of the study; in the collection, analyses, or interpretation of data; in the writing of the manuscript, or in the decision to publish the results. 


\section{Appendix A}

Table A1. List of clubs participating in the Bajtek Golden Disk Contest (1987).

\begin{tabular}{|c|c|c|c|}
\hline Club Name & Place & Established & $\begin{array}{c}\text { Location } \\
\text { (Sponsor, Patron) }\end{array}$ \\
\hline $\begin{array}{l}\text { Amstrad-Schneider } \\
\text { Club }\end{array}$ & Bełchatów & ND & $\begin{array}{l}\text { Mining and Power School } \\
\text { Complex in Bełchatów }\end{array}$ \\
\hline ATARI & Choszczno & 1986 & $\begin{array}{c}\text { Community centre in } \\
\text { Choszczno }\end{array}$ \\
\hline ATARI & Olsztyn & 1986 & Dairy cooperative JAROTY \\
\hline ATARI & Wręczyca Wielka & ND & Forest Board in Wręczyca \\
\hline ATARI TEST & $\begin{array}{l}\text { Piotrków } \\
\text { Trybunalski }\end{array}$ & ND & $\begin{array}{c}\text { Voivodeship community } \\
\text { centre in Piotrków } \\
\text { Trybunalski }\end{array}$ \\
\hline BAJT & Łazy & 1986 & $\begin{array}{l}\text { Scout Troop Command } \\
\text { in Łazy }\end{array}$ \\
\hline BAJTEK & Kraków & 1986 & $\begin{array}{c}\text { Board of the Polish Socialist } \\
\text { Youth Union for } \\
\text { Kraków-Śródmieście }\end{array}$ \\
\hline BAJTEK & Zamość & 1986 & $\begin{array}{l}\text { J. Zamoyski First } \\
\text { Secondary School } \\
\text { in Zamość }\end{array}$ \\
\hline BIT & Warsaw & 1986 & No patron \\
\hline BOBAS-ATARI & Gliwice & ND & Informal club, no venue \\
\hline C.C. ATARI & Choszczno & ND & $\begin{array}{c}\text { Community centre in } \\
\text { Choszczno }\end{array}$ \\
\hline CELBIT & Kwidzyn & 1986 & $\begin{array}{c}\text { Paper factory Zakłady } \\
\text { Papiernicze w Kwidzynie }\end{array}$ \\
\hline CHOMIK & Warsaw & 1986 & $\begin{array}{l}\text { CHOMICZÓWKA } \\
\text { Resident Club }\end{array}$ \\
\hline $\begin{array}{l}\text { COMMODORO- } \\
\text { BAJT-CLUB }\end{array}$ & Bydgoszcz & 1987 & No patron \\
\hline DK MASTERS & Rawicz & ND & $\begin{array}{l}\text { Community centre } \\
\text { in Rawicz }\end{array}$ \\
\hline FENIKS & $\operatorname{Recz}$ & 1986 & $\begin{array}{l}\text { Town and municipality } \\
\text { community centre in Recz }\end{array}$ \\
\hline Future & Oleśnica & ND & Informal club, no venue \\
\hline $\begin{array}{c}\text { Harcerski Klub } \\
\text { Komputerowy } \\
\text { HarcBajt }\end{array}$ & Gdańsk & 1987 & $\begin{array}{c}\text { Scout Regiment Command } \\
\text { in Gdańsk, Scouts' House } \\
\text { in Gdańsk }\end{array}$ \\
\hline $\begin{array}{l}\text { Harcerskie Centrum } \\
\text { Komputerowe }\end{array}$ & Lublin & ND & $\begin{array}{l}\text { Scout Regiment Command } \\
\text { in Lublin }\end{array}$ \\
\hline INFORMIK & Bydgoszcz & 1986 & No patron \\
\hline INFORMIK & Olkusz & 1986 & $\begin{array}{c}\text { Primary School No. } 1 \\
\text { in Olkusz }\end{array}$ \\
\hline Klub komputerowy & Mielec & ND & $\begin{array}{l}\text { Community centre WSK } \\
\text { "PZL-Mielec" }\end{array}$ \\
\hline $\begin{array}{c}\text { Klub Komputerowy } \\
\text { MMT ALFA }\end{array}$ & $\begin{array}{c}\text { Stargard } \\
\text { Szczeciński }\end{array}$ & ND & $\begin{array}{l}\text { Housing cooperative in } \\
\text { Stargard Szczeciński }\end{array}$ \\
\hline
\end{tabular}


Table A1. Cont.

\begin{tabular}{|c|c|c|c|}
\hline Club Name & Place & Established & $\begin{array}{c}\text { Location } \\
\text { Sponsor, Patron) }\end{array}$ \\
\hline $\begin{array}{c}\text { Klub Komputerowy } \\
\text { MMT BIN }\end{array}$ & Turek & ND & $\begin{array}{c}\text { Polish Socialist Youth } \\
\text { Union in the Adamów } \\
\text { Brown Coal Mine in Turek }\end{array}$ \\
\hline $\begin{array}{c}\text { Klub Komputerowy } \\
\text { przy Pałacu } \\
\text { Młodzieży w } \\
\text { Szczecinie }\end{array}$ & Szczecin & 1986 & Palace of Youth in Szczecin \\
\hline LOK & Nowy Sacz & 1986 & $\begin{array}{l}\text { Voivodeship Board of the } \\
\text { National Defence League }\end{array}$ \\
\hline MAD BOYS ATARI & Żyrardów & ND & Informal club, no venue \\
\hline MANIAK & Warsaw & 1985 & $\begin{array}{l}\text { Neighbourhood club } \\
\text { in Ursynów }\end{array}$ \\
\hline MERIZAP & $\begin{array}{c}\text { Ostrów } \\
\text { Wielkopolski }\end{array}$ & 1985 & $\begin{array}{l}\text { MERIZAP Complex of } \\
\text { Technical Schools } \\
\text { in Ostrów }\end{array}$ \\
\hline METRO-POST & $\begin{array}{l}\text { Piotrków } \\
\text { Trybunalski }\end{array}$ & 1986 & Primary school No. 3 \\
\hline $\begin{array}{c}\text { Młodzieżowy Klub } \\
\text { Komputerowy } \\
\text { MIKROBAJT }\end{array}$ & Łódź & ND & $\begin{array}{l}\text { Inter-company club of } \\
\text { printing industry } \\
\text { employees "Chochlik" }\end{array}$ \\
\hline MNEMONIK & Wrocław & 1986 & $\begin{array}{l}\text { Electronics factory Zakłady } \\
\text { Elektroniczne ELWRO }\end{array}$ \\
\hline Mr ATARI & Kozienice & 1985 & No patron \\
\hline POLTRONIC & Częstochowa & 1987 & No patron \\
\hline SAVE & Słupca & 1985 & $\begin{array}{l}\text { M Jackowski Economics } \\
\text { Schools Complex in Słupca }\end{array}$ \\
\hline SINCLAIR CLUB & Kraków & 1985 & No patron \\
\hline SPECTRUM & Lublin & ND & $\begin{array}{c}\text { Mechanical and Power } \\
\text { Engineering School } \\
\text { Complex }\end{array}$ \\
\hline SYNTAX ERROR & Koszalin & 1986 & Association of Rural Youth \\
\hline TIME-Studio & Łęczna & ND & $\begin{array}{c}\text { Secondary School Complex } \\
\text { in Łęczna }\end{array}$ \\
\hline TOMBIT & Stegna Gdańska & 1986 & No patron \\
\hline WITEŹ & Kielce & 1986 & $\begin{array}{l}\text { Microcomputer } \\
\text { inspectorate of Scout } \\
\text { Regiment Command }\end{array}$ \\
\hline ZŁOTY AMSTRAD & Złoty Stok & 1987 & $\begin{array}{l}\text { Zakład Tworzyw i Farb } \\
\text { Złoty Stok, plant } \\
\text { community centre }\end{array}$ \\
\hline
\end{tabular}


Table A2. Resources available in selected computer clubs in Poland in the 1980s.

\begin{tabular}{|c|c|c|c|c|c|}
\hline Place & $\begin{array}{l}\text { Name of the } \\
\text { Club or } \\
\text { Association }\end{array}$ & $\begin{array}{l}\text { Members/ } \\
\text { Established }\end{array}$ & Computers Available & $\begin{array}{l}\text { Location (Tutor, } \\
\text { Sponsor, Patron) }\end{array}$ & Reference \\
\hline Raciążek & Bajtuś & $25 / 1986$ & $\begin{array}{l}\text { Commodore C64 } \\
\text { (2 units) }\end{array}$ & $\begin{array}{c}\text { Municipality } \\
\text { community centre }\end{array}$ & [33] \\
\hline Warsaw & ABAKUS & ND/1984 & $\begin{array}{c}\text { Atari } 800 \mathrm{XL}, \\
\text { Commodore C64, ZX } \\
\text { Spectrum, Amstrad } \\
\text { 464, Schneider PC } \\
\text { 1512, and others }\end{array}$ & $\begin{array}{l}\text { ABAKUS } \\
\text { microcomputer } \\
\text { association }\end{array}$ & [33] \\
\hline Wrocław & MNEMONIK & ND/1986 & Polish computer Junior & $\begin{array}{c}\text { Electronics factory } \\
\text { Zakłady } \\
\text { Elektroniczne } \\
\text { ELWRO }\end{array}$ & [34] \\
\hline Oleśnica & FUTURE & $12 / \mathrm{ND}$ & Commodore C64 & $\begin{array}{c}\text { Room in a } \\
\text { neighbourhood club }\end{array}$ & {$[34]$} \\
\hline Przemyśl & $\begin{array}{l}\text { Centrum } \\
\text { Komputerowe } \\
\text { Młodzieżowego } \\
\text { Ruchu Kultury w } \\
\text { Przemyślu }\end{array}$ & ND/1987 & $\begin{array}{c}\text { Spectrum Plus } \\
\text { (5 units), Atari } 800 \text { XL } \\
\text { (9 units), Atari } 130 \text { XE } \\
\text { (1 unit) }\end{array}$ & $\begin{array}{l}\text { Youth community } \\
\text { centre in Przemyśl }\end{array}$ & [15] \\
\hline Koszalin & $\begin{array}{l}\text { Szkolne Kółko } \\
\text { Komputerowe }\end{array}$ & ND/1986 & $\begin{array}{c}\text { No hardware Work } \\
\text { based on computer } \\
\text { publications }\end{array}$ & $\begin{array}{c}\text { W. Broniewski } \\
\text { Second Secondary } \\
\text { School in Koszalin }\end{array}$ & [15] \\
\hline Kwidzyn & CELBIT & $200 / 1986$ & $\begin{array}{c}\text { Timex (3 units), Polbrit } \\
\text { (3 units), Atari 800XL } \\
\text { (3 units), Commodore } \\
\text { C64 (1 unit), IBM XT } \\
\text { (unit) }\end{array}$ & $\begin{array}{l}\text { Cellulose factory } \\
\text { Zakłady Celulozowo- } \\
\text { Papiernicze w } \\
\text { Kwidzynie; local } \\
\text { community hall in } \\
\text { Zatorze II, city } \\
\text { community centre }\end{array}$ & [9] \\
\hline Złoty Stok & $\begin{array}{c}\text { ZŁOTY } \\
\text { AMSTRAD }\end{array}$ & $130 / 1987$ & $\begin{array}{l}\text { Amstrads, including } \\
\text { the Amstrad PC } 1512\end{array}$ & $\begin{array}{l}\text { Plastics and paint } \\
\text { factory Zakłady } \\
\text { Tworzyw i Farb in } \\
\text { Złoty Stok }\end{array}$ & [9] \\
\hline Gdańsk & HarcBajt & $10 / 1987$ & ND & $\begin{array}{l}\text { Scouts' computer } \\
\text { club-Scouts' House } \\
\text { in Gdańsk }\end{array}$ & [9] \\
\hline Szczecin & $\begin{array}{l}\text { Klub Mikrokom- } \\
\text { puterowy }\end{array}$ & $104 / 1987$ & $\begin{array}{l}\text { ZX Spectrum Plus } \\
\quad \text { (4 units) }\end{array}$ & $\begin{array}{c}\text { Part of young } \\
\text { electronics engineers } \\
\text { club }\end{array}$ & [6] \\
\hline Warsaw & BIT & $4 / 1986$ & Amstrad & Family club & [16] \\
\hline Warsaw & MERIZAP & ND/1985 & $\begin{array}{c}\text { Mera 302, 303, 305, } \\
\text { Mera 400, IBM, } \\
\text { Amstrad 6128, } \\
\text { Commodore 64 } \\
\text { (7 units), Commodore } \\
\text { Plus 4, Spectrum } \\
\text { (14 units), Timex } \\
\text { (3 units), ZX } 81\end{array}$ & $\begin{array}{l}\text { Industrial automation } \\
\text { manufacturer } \\
\text { Zakłady Automatyki } \\
\text { Przemysłowej } \\
\text { MERAZAP }\end{array}$ & [16] \\
\hline Kozienice & ATARI & $17 / 1985$ & $\begin{array}{l}\text { Atari 130XE, 800XL, } \\
\text { 1050, } 12 \mathrm{XC}\end{array}$ & No patron & [16] \\
\hline Łazy & BAJT & $15 / 1986$ & $\begin{array}{l}\text { ZX Spectrum (2 units), } \\
\text { Timex (3 units) }\end{array}$ & $\begin{array}{c}\text { Scout Troop } \\
\text { Command in Łazy }\end{array}$ & [16] \\
\hline Warsaw & MIKROS & $150 / 1984$ & $\begin{array}{l}\text { ZX Spectrum, Atari } \\
\text { 800XL, Meritum I, } \\
\text { UNIPOLBRIT } 2086\end{array}$ & $\begin{array}{l}\text { Radio manufacturer } \\
\text { Zakłady Radiowe im. } \\
\text { Marcina Kasprzaka } \\
\text { in Warsaw }\end{array}$ & [36] \\
\hline
\end{tabular}

Source: original work based or reports in Bajtek.

\section{References}

1. Watt, D. Logo in the Schools. Byte Mag. 1982, 7, 116-122. Available online: https:/ /archive.org/details/byte-magazine-1982-08/ page/n117/ (accessed on 26 November 2021).

2. Jardim, J. Entrepreneurial Skills to Be Successful in the Global and Digital World: Proposal for a Frame of Reference for Entrepreneurial Education. Educ. Sci. 2021, 11, 356. [CrossRef]

3. Luik, P.; Taimalu, M. Predicting the Intention to Use Technology in Education among Student Teachers: A Path Analysis. Educ. Sci. 2021, 11, 564. [CrossRef]

4. Carballo, A.; Espinoza, E.L.; Almira, J.S.; Yero, I. Approach to the Formulation of the Variable Change Theorem. Educ. Sci. 2021, 11, 357. [CrossRef] 
5. Feklistova, L.; Lepp, M.; Luik, P. Learners' Performance in a MOOC on Programming. Educ. Sci. 2021, 11, 521. [CrossRef]

6. Kowalski, Z. Komputer ci pomoże. Bajtek Mag. 1987, 5, 27. Available online: https://archive.org/details/bajtek198705/page/n25/ (accessed on 26 November 2021).

7. Piotrowski, W. Najtrudniejszy pierwszy krok. Bajtek Mag. 1986, 3-4, 29. Available online: https://archive.org/details/bajtek198 60304/page/n27/ (accessed on 26 November 2021).

8. Konkurs o Złotą Dyskietkę Bajtka (Press Release). Bajtek Mag. 1989, 6, 30. Available online: https://archive.org/details/bajtek1 98906/page/n29/ (accessed on 26 November 2021).

9. Konkurs o Złotą Dyskietkę Bajtka (Press Release). Bajtek Mag. 1989, 5, 24-25. Available online: https://archive.org/details/ bajtek198905/page/n23/ (accessed on 26 November 2021).

10. Kolasa, W.M. Polskie czasopisma komputerowe. Cz. 1. Zarys statystyczno-opisowy. Informatyka 1999, 3, 10-16.

11. Cetera, W. IKS-Informatyka, Komputery, Systemy 1986-1989. Studium Przypadku; Instytut Dziennikarstwa Uniwersytetu Warszawskiego: Warszawa, Polska, 2016.

12. Kolasa, W.M. Polskie czasopisma komputerowe. Cz. 2. Magazyny komputerowe 1985-1989. Informatyka 1999, 4, 10-13.

13. Filiciak, M. Gra w kapitalizm. PRL, konstruowanie pamięci i gry cyfrowe. Widok. Teor. I Prakt. Kult. Wizualnej 2015, 11. Available online: http:/ / widok.hmfactory.com/index.php/one/article/view/314/677 (accessed on 26 November 2021).

14. Król, K.; Czesak, B. The Beginnings of Digital Heritage; Publishing House of the University of Agriculture: Krakow, Poland, 2021. [CrossRef]

15. Włoszczyński, W. Bajtek z Zamościa. Bajtek Mag. 1987, 4, 26-27. Available online: https://archive.org/details/bajtek198704/ page/n25/ (accessed on 26 November 2021).

16. Ryczaj, A.; Ćwieka, W. Komputery podbijają Przemyśl. Bez komputera. Bajtek Mag. 1987, 1, $28-29$.

17. Poznański, R. Rozstrzygnięcie konkursu o Złota Dyskietkę Bajtka. Bajtek Mag. 1987, 11, 28-29. Available online: https: / / archive.org/details/bajtek198711/page/n27/ (accessed on 26 November 2021).

18. Konkurs o Złotą Dyskietkę Bajtka (Press Release). Bajtek Mag. 1988, 10, 29.

19. Król, K. Hardware Heritage-Briefcase-Sized Computers. Heritage 2021, 4, 2237-2252. [CrossRef]

20. Moyer, J.C.; Robison, V.; Cai, J. Attitudes of high-school students taught using traditional and reform mathematics curricula in middle school: A retrospective analysis. Educ. Stud. Math. 2018, 98, 115-134. [CrossRef]

21. Kolasa, W.M. Prasa komputerowa w Polsce-historia i statystyka. Ann. Acad. Paedagog. Crac. Studia Ad Bibl. Sci. Pertin. 2001, 1 , 109-135.

22. Calma, A.; Davies, M. Studies in Higher Education1976-2013: A retrospective using citation network analysis. Stud. High. Educ. 2014, 40, 4-21. [CrossRef]

23. Yu, D.; Xu, Z.; Pedrycz, W.; Wang, W. Information sciences 1968-2016: A retrospective analysis with text mining and bibliometric. Inf. Sci. 2017, 418-419, 619-634. [CrossRef]

24. Jeffs, T.; Morrison, W.F.; Messenheimer, T.; Rizza, M.G.; Banister, S. A Retrospective Analysis of Technological Advancements in Special Education. Comput. Sch. 2003, 20, 129-152. [CrossRef]

25. Kholoshyn, I.; Nazarenko, T.; Bondarenko, O.; Hanchuk, O.; Varfolomyeyeva, I. The application of geographic information systems in schools around the world: A retrospective analysis. J. Phys. Conf. Ser. 2021, 1840, 12017. [CrossRef]

26. Peled, Y.; Kali, Y.; Dori, Y.J. School principals' influence on science teachers' technology implementation: A retrospective analysis. Int. J. Leadersh. Educ. 2011, 14, 229-245. [CrossRef]

27. Martinez-Prather, K.; Vandiver, D.M. Sexting among teenagers in the United States: A retrospective analysis of identifying motivating factors, potential targets, and the role of a capable guardian. Int. J. Cyber Criminol. 2014, 8, 21-35.

28. Burton, B.; Kumar, S.; Pandey, N. Twenty-five years of The European Journal of Finance (EJF): A retrospective analysis. Eur. J. Finance 2020, 26, 1817-1841. [CrossRef]

29. Gammelgaard, B.; Kumar, S.; Pattnaik, D.; Joshi, R. Thirty years of the International Journal of Logistics Management-a retrospective analysis. Int. J. Logist. Manag. 2020, 31, 173-208. [CrossRef]

30. Jabbour, J.; Flachsland, C. 40 years of global environmental assessments: A retrospective analysis. Environ. Sci. Policy 2017, 77, 193-202. [CrossRef]

31. Filkov, A.I.; Ngo, T.; Matthews, S.; Telfer, S.; Penman, T.D. Impact of Australia's catastrophic 2019/20 bushfire season on communities and environment. Retrospective analysis and current trends. J. Saf. Sci. Resil. 2020, 1, 44-56. [CrossRef]

32. Siwiński, W. Kształcenie narybku. Bajtek Mag. 1989, 4, 21. Available online: https://archive.org/details/bajtek198904/page/n19/ (accessed on 26 November 2021).

33. Drugi Bajtek w Bytomiu (Press Release). Bajtek Mag. 1987, 8, 29. Available online: https://archive.org/details/bajtek198708/ page/n27/ (accessed on 26 November 2021).

34. Konkurs o Złotą Dyskietkę Bajtka (Press Release). Bajtek Mag. 1989, 8, 30. Available online: https://archive.org/details/bajtek1 $98908 /$ page/n29/ (accessed on 26 November 2021).

35. Maćkowiak, B.; Myszkier, A.; Safader, B. Polskie Komputery Rodzity Się W ELWRO We Wroctawiu. Rola Wrocławskich Zakładów Elektronicznych ELWRO W Rozwoju Informatyki W Polsce; Archiwum Państwowe we Wrocławiu: Wrocław, Polska, 2017.

36. Kłóskiewicz, A.; Pieczerak, P. Klub Mikros. Bajtek Mag. 1986, 8, 26-27. Available online: https://archive.org/details/bajtek19860 8/page/n25/ (accessed on 26 November 2021). 
37. Konkurs o Złotą Dyskietkę Bajtka (Press Release). Bajtek Mag. 1987, 10, 29. Available online: https://archive.org/details/bajtek1 98710/page/n27/ (accessed on 26 November 2021).

38. Czarkowski, M. Ściśle jawne. Bajtek Mag. 1989, 8, 3. Available online: https://archive.org/details/bajtek198908/page/n1/ (accessed on 26 November 2021).

39. Polak, S.; Wojciechowski, R. Hobby dla myślacych. Bajtek Mag. 1987, 1, 3. Available online: https://archive.org/details/bajtek1 98701/page/n1/ (accessed on 26 November 2021).

40. Łojewski, J.; Kuzora, P. Klub nad Renem. Bajtek Mag. 1988, 12, 29. Available online: https://archive.org/details/bajtek_88_12/ page/n27/ (accessed on 26 November 2021).

41. Jaszczuk, B.K. W bratysławskim T-Klubie. Bajtek Mag. 1987, 3, 27. Available online: https://archive.org/details/bajtek198703/ page/n25/ (accessed on 26 November 2021).

42. Radio Shack's Commitment to Education. Creat. Comput. 1985, 11, 12. Available online: https://archive.org/details/Creative Computing_1985-03/page/n13/ (accessed on 26 November 2021). 